\title{
ÁREAS DE RISCOS, MOBILIDADE URBANA, VULNERABILIDADE E O PODER PÚBLICO EM CUIABÁ/MT: PORQUE A POPULAÇÃO CONTINUA VIVENDO NAS ÁREAS DE RISCO DO CÓRREGO DO BARBADO?
}

\author{
ZAMPARONI, Cleusa Aparecida Gonçalves Pereira - cazamp@gmail.com \\ Dept Geografia - Universidade Federal do Mato Grosso
}

\begin{abstract}
RESUMO: O presente artigo buscou investigar as razões que levam a população que vive em áreas de riscos a retornarem para suas casas após os períodos mais críticos dos desastres naturais. Para isso, foi necessário ir além dos problemas derivados dos episódios das enchentes e alagamentos que ocorrem nas margens do Córrego do Barbado (Cuiabá/MT) para compreender o sentimento de pertencimento que liga esta população às áreas de riscos, tendo como referencial os laços que unem os habitantes dos locais afetados, o modo de vida e as aspirações que possuem no que se refere às principais dimensões da vida social, do bem-estar e das condições econômicas.
\end{abstract}

Palavras-chave: Risco, vulnerabilidade, mobilidade, desastres naturais, córrego Barbados, Cuiabá--MT RISK AREAS, URBAN MOBILITY, VULNERABILITY AND PUBLIC POWER IN CUIABÁ / MT: WHY POPULATION STEAL LIVES RISK AREAS OF BARBADO STREAM

ABSTRACT: This paper investigates the reasons why the population living in areas at risk returns to their homes after the most critical periods of natural disasters. For this it was necessary to go beyond the problems derived from episodes of flooding occurring on the banks of the stream Barbados (Cuiabá / MT) to understand the feeling of belonging that connects this population at risk areas, taking as reference the ties that unite the inhabitants of the affected areas, the way of life and aspirations they have in relation to key dimensions of social, welfare and economic conditions.

Keywords: Risk, vulnerability, mobility, flooding, stream Barbados, Cuiabá - MT

\section{INTRODUÇÃO}

A problemática urbana no Brasil tem como premissa básica a desigualdade de acesso aos bens e serviços, resultando em elevado déficit habitacional e situações de informalidade urbana caracterizadas pela precariedade de infraestrutura básica e de saneamento ambiental. Sobre a temática, ressalta-se quão oportuna é a leitura de Maricato (2010) cujos pressupostos apontam que no país ocorre a desregulamentação dos serviços públicos, a guerra fiscal e o enfraquecimento do papel social do Estado, dessa forma, o espaço urbano encontra-se fortemente segregado pelo mercado imobiliário e por investimentos públicos que sempre foram aplicados de forma concentrada e socialmente regressiva.

O ambiente urbano no século XXI caracteriza-se pela elevada densidade demográfica e por questões socioambientais dela decorrente, entre elas, destaca-se a desigualdade de renda e da oferta de bens e serviços assim, eventos esportivos de relevância global são disputados pelos países, com o objetivo de atrair investimentos e estimular o desenvolvimento econômico.

A Copa do mundo de 2014 foi realizada no Brasil e a FIFA elegeu 10 cidades para sediarem o evento, Cuiabá esteve entre os locais escolhidos, e assim, várias obras foram realizadas, em especial, no tocante à mobilidade urbana, como correlato, remanejar famílias que atualmente vivem em locais considerados áreas de risco.

Neste contexto de construções/remanejamento esteve contemplada à construção da Avenida Parque do Barbado, onde vive uma parte da população que, há 25 anos aproximadamente, ocupando de forma irregular os bairros Belos Vista, Castelo Branco, Pedregal e Renascer localizados em Áreas de Proteção Permanente (APP's) onde ocorrem episódios de enchentes e alagamentos na estação chuvosa.

A ocupação das referidas áreas evidencia que a oportunidade de uma vida com qualidade não se apresenta da mesma forma para todos, assim, parte da população, especialmente dos setores menos favorecidos economicamente, residem em locais impróprios para moradia, por oferecerem riscos à vida, especialmente nas encostas e margens de rios, como nas Áreas de Preservação Permanente - APP's. (MATTEDI e BUTZKE, 2001; CARVALHO e GALVÃO, 2006; 
NUNES, 2009). Este tipo de ocupação tem sido permitidopelos órgãos de planejamento urbano como medidas paliativas para resolver temporariamente problemas sociais e com isso, provocado relevantes mudanças na configuração espacial das cidades mescladas com as ampliações das demandas sociais e ambientais na escala local (GUERRA \& CUNHA, 2001).

Em Cuiabá, percebe-se que o processo de ocupação das áreas urbanas produziu espaços desiguais resultantes, provavelmente, da estrutura econômica, política e cultural do país ao longo de sua história. Nesse sentido, estudos que contribuam para a compreensão da evolução urbana em faixas marginais de cursos d'agua urbanos, com ênfase nos diversos processos que permitiram a alteração de suas características originais, à luz da legislação urbana e ambiental vigente, podem se tornar instrumentos imprescindíveis para a gestão ambiental das Áreas de Preservação Permanentes e os riscos a desastres naturais.

Castro (2009) coloca que o município de Cuiabá possui 36 córregos que deságuam nos rios Cuiabá e Coxipó e a população, à medida que foi se expandindo, ocupou as Áreas de Preservação Permanente existentes no ambiente urbano, consequentemente os mananciais aquíferos encontram-se contaminados com entulhos e lixos de toda a espécie contribuindo com entupimentos e servindo de barreira para o escoamento das águas pluviais. Nestes locais vive a população que tem sido mais atingida pelos episódios de enchentes, na estação chuvosa. A Defesa Civil de Cuiabá contabilizou 1.377 hectares de área de risco na cidade de Cuiabá, sendo que a maioria está ocupada de forma irregular.

Pesquisas realizadas por Bordest (2003) afirmam que o Córrego do Barbado, tributário do Rio Cuiabá, possui 9.400 metros de extensão e tem sua sub-bacia totalmente inserida no perímetro urbano. A ocupação dessa área ocorreu principalmente a partir da década de 70 do século XX com a construção do Centro Político Administrativo (CPA), na porção nordeste da cidade, na região das cabeceiras do córrego e com a instalação da Universidade Federal de Mato Grosso (UFMT) na área central da bacia em 1972. Como esses dois pólos de expansão estavam, na época, localizados em regiões afastadas da área central da cidade, foram deixadas ao longo do perímetro, grandes manchas de vazios urbanos, onde inicialmente foram abertos loteamentos residenciais de classe média e média alta e posteriormente algumas áreas foram invadidas para uso residencial de famílias de baixa renda.

Na sub-bacia do Córrego do Barbado vivem 51.320 pessoas distribuídas em 22 bairros, onde 11 bairros são regulares e 11 são oriundos de invasões (IPDU, 2002) As ocupações irregulares nas APP's ao longo do córrego, nascentes, e várzeas, ocorreram sem que houvesse cumprimento das legislações ambientais e urbanísticas locais, como correlato, a sub-bacia do Barbado é um espaço, heterogêneo, marcado por fortes contradições sociais, onde tanto os bairros formais quanto os informais, têm em comum o fato de não serem servidos de rede de esgoto e por usarem o córrego do Barbado como receptáculo do esgoto doméstico.

Diante da situação apresentada, ressalta-se a necessidade das análises técnicas como instrumentos de apoio ao poder público, no sentido de minimizar os impactos socioambientais e, de forma concomitante, estimular a participação da população nesse processo. Nas palavras de Buarque (1990) toda decisão e definição de planejamento resultam de uma disputa política dos atores, cada um procurando influenciar no projeto coletivo com suas próprias expectativas em relação ao futuro assim, é imprescindível a participação das múltiplas instancia nos processos decisórios.

Kothari (2011) ao discutir o direito à moradia adequada enfatiza a importância da avaliação dos impactos dos projetos que envolvem remanejamento populacional, especialmente em relação à população mais vulnerável e recomenda a necessidade de considerar os aspectos econômicos no mesmo patamar de importância dos aspectos sociais e culturais, respeitando, inclusive, as condições de convivência pré-existentes, dessa forma, o deslocamento das famílias requer necessariamente um processo de gestão voltado à manutenção e melhoria da qualidade de vida.

Assim, o presente artigo buscou investigar as razões que levam a população que vive em áreas de riscos retornarem para suas casas após os períodos mais críticos dos desastres naturais. Para isso, foi necessária ir além dos problemas derivados dos episódios das enchentes e alagamentos que ocorrem nas margens do Córrego do Barbado para compreender o sentimento de pertencimento que liga esta população às áreas de riscos tendo como 
referencial os laços que unem os habitantes dos locais afetados, o modo de vida e as aspirações que possuem no que se refere às principais dimensões da vida social, do bem-estar e das condições econômicas.

\section{2. ÁREA DE ESTUdOS}

O município de Cuiabá localiza-se no Estado de Mato Grosso, nas Coordenadas Geográficas de $15^{\circ} 35^{\prime} 56^{\prime \prime}$ de latitude Sul e 56 $6^{\circ} 6^{\prime} 01^{\prime \prime}$ de longitude oeste. Os bairros da Bela Vista, Castelo Branco, Pedregal e Renascer localizam-se em Áreas de Proteção Permanente (APP's) do Córrego do Barbado (Figura 1).
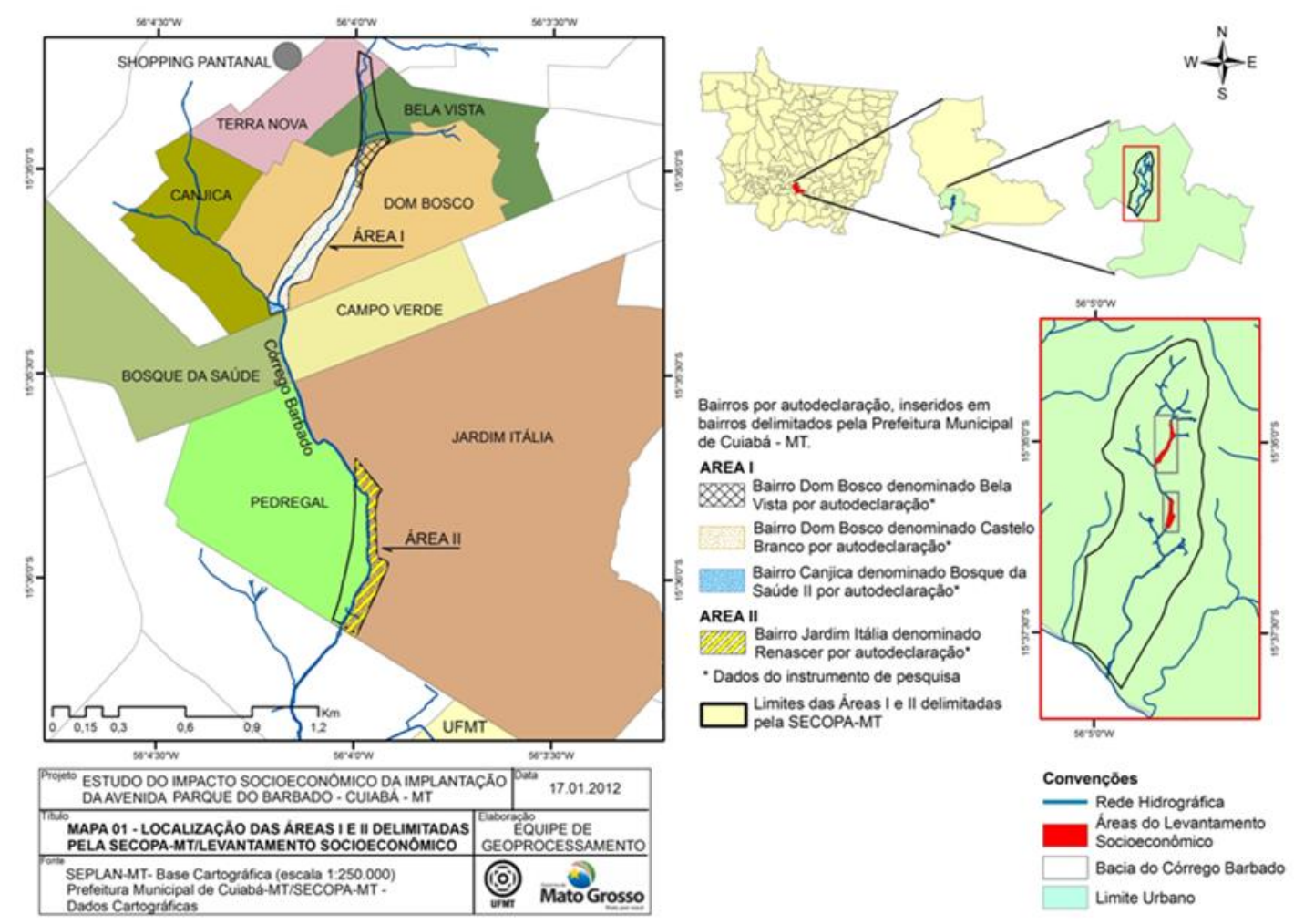

Figura 1- Localização do Córrego do Barbado e os bairros:Bela Vista, Castelo Branco, Pedregal e Renascer.

Segundo Guarim (1990) sua cobertura vegetal é constituída principalmente pela vegetação de cerrado e a mata ciliar aparece próxima aos córregos. Nas áreas periféricas da cidade, domina a vegetação de cerrado, com árvores de até 4 metros de altura, caule e ramos retorcidos, suberosos, folhas ceriáceas, com copas que se tocam e cerradão, tipo vegetacional florestal de cerrado, com árvores de 8 metros de altura e copas entrelaçadas. A mata ciliar acompanha os corpos d'agua e tem árvores com 10 metros de altura. A mata semidecídua e a mata de encosta, com espécies arbóreas, com estratos contínuos de 10 metros de altura, ocorrem mescladas aos demais tipos de vegetação e nas áreas de relevo mais acentuado. Assim, a vegetação nativa da região e espécies remanescentes do cerrado forma um verdadeiro cinturão verde em torno da área urbanizada de Cuiabá .

O clima é resultado da interação entres os eventos atmosféricos e a superfície terrestre. Assim, para a realização da classificação climática de uma região, alguns parâmetros são utilizados, tais como a temperatura, precipitação, latitude, altitude, entre outros (MAITELLI, 1994). O clima regional, conforme o modelo de Thornthwaite, tem como principal característica a sazonalidade, fator essencial para a sua classificação. Cuiabá se encontra sob a 
influência regional de regime pluviométrico tipicamente tropical, com dois períodos sazonais: um chuvoso, de novembro a março, com cerca de $80 \%$ da precipitação anual, e outro seco, de abril a outubro, sendo o inverno coincidente com esse período, com quedas acentuadas de temperatura e precipitações pequenas ou quase nulas, nos meses de junho e julho. Cuiabá, na classificação de Köppen, pertence ao Clima de Savana (Aw), o qual possui um clima tropical, com estação seca (outono-inverno) e estação chuvosa (primavera-verão), com temperatura média anual de $25^{\circ} \mathrm{C}$ e pluviosidade anual de $1.450 \mathrm{~mm}$.

A maior parte das áreas de risco às enchentes se localiza às margens do rio Cuiabá e suas adjacências, e parte da população de baixa renda vive nessas localidades. Em Cuiabá, a ocupação desordenada e a falta de políticas públicas de preservação da rede hídrica e de investimentos em saneamento e coleta de lixo estão provocando aumento significativo de inundações em bairros situados na área de inundação do rio Cuiabá. Diferentemente das enchentes do rio, ocorridas em 1942, 1974, 1995 e 2001 em função de alto índice pluviométrico em todo o planalto da Bacia do Rio Cuiabá, as inundações recentes estão mais relacionadas com erosões e entupimento das calhas dos 36 córregos que cortam a capital e deságuam nos rios Cuiabá e Coxipó.

Cuiabá possui 36 córregos que deságuam nos rios Cuiabá e Coxipó. Castro Jr. (2009) detectou que em $80 \%$ dos córregos já não há vida, pois estão contaminados com entulhos e lixos de toda a espécie, contribuindo com entupimentos e servindo de barreira para 0 escoamento das águas pluviais. Nesses locais, vive a população que tem sido mais atingida pelos episódios de enchentes, na estação chuvosa.

A ocupação urbana ao longo da sub-bacia do Barbado e, consequentemente, a impermeabilização de seu território, ampliaram o escoamento superficial, a velocidade e a quantidade do fluxo das águas precipitadas. As obras de drenagem presentes no baixo curso agravaram as enchentes na foz do Barbado, causando danos não só ao ambiente físico, mas principalmente à população, afetando a segurança, a saúde, e trazendo prejuízos materiais.

Para Zamparoni (2012) os desastres naturais e situações de risco em Cuiabá/MT foram sendo engendrados no processo histórico de ocupação espacial da cidade e, por isso, são derivados de uma combinação de antigas desigualdades socioambientais com novas formas adquiridas nas últimas décadas do século $X X$.

O processo de migração oficial e privada dirigidos pelo estado e apoiados em políticas públicas como o PIN - Programas de Integração Nacional promoveu mudanças relevantes na cidade de Cuiabá a partir da década de 1970.

Em Cuiabá, a ocupação desordenada e a falta de políticas públicas de preservação da rede hídrica e de investimentos em saneamento e coleta de lixo provocam aumento significativo de inundações em bairros situados na área de inundação do rio Cuiabá, APP's (Areas de Proteção Permanente) e nos córregos.

\section{PROCEDIMENTOS METOdOLÓgicos}

Os procedimentos metodológicos adotados para atingir os objetivos proposotos nesta investigação apresentam três recortes complementares, sendo que o primeiro foi a elaboração do projeto e sua articulação e discussão nas várias instâncias envolvidas, buscando estabelecer uma linguagem comum entre os atores sociais, ou seja, gestores públicos, técnicos institucionais e a população local. Tal etapa foi denominada "preparatória".

O segundo recorte compreendeu a fase de diagnóstico e explicitou as técnicas adotadas para a coleta e organização de informações secundárias, para a organização espacial da coleta de dados em campo, realização das entrevistas, organização e cadastramento de informações no banco de dados.

A terceira fase denominada de "prognóstico" buscou analisar os resultados e propor medidas aos impactos positivos e negativos para a população atingida, expressas por eixos prioritários que possivelmente direcionarão as ações do poder público. 
Tal trajetória visou contemplar diferentes perspectivas que, não obstante, se combinam e se confrontam, assegurando a qualidade técnica com base na participação política da população envolvida.

Seguindo os objetivos definidos para a pesquisa, foi elaborado um instrumento de coleta de dados contendo 194 questões divididas em 15 seções que fornecem informações sobre o responsável e também sobre os demais membros que compõem a família dos entrevistados. (Quadro 1).

\begin{tabular}{|c|c|}
\hline Identificação das Seções & Objetivos/características \\
\hline Seção I - Monitoramento das entrevistas & $\begin{array}{l}\text { Identifica a data, horário de início e final, bem como o } \\
\text { status da entrevista. }\end{array}$ \\
\hline Seção II - Identificação do domicilio & $\begin{array}{l}\text { Fornecem dados sobre a identificação de cada domicílio da } \\
\text { área de estudo no que se refere à sua localização na área, } \\
\text { no setor, no croqui, o número do domicílio (residência), o } \\
\text { número da família e o número da entrevista. }\end{array}$ \\
\hline $\begin{array}{l}\text { Seção III - Endereço do domicílio e } \\
\text { identificação do responsável pela família }\end{array}$ & $\begin{array}{l}\text { Mostra a quantidade de famílias residentes no domicílio e } \\
\text { respectiva quantidade de casas no lote. Além de nome do } \\
\text { responsável pela família; endereço; informação sobre } \\
\text { escritura da casa; dados dos documentos pessoais do } \\
\text { entrevistado; e assinatura do mesmo. }\end{array}$ \\
\hline $\begin{array}{l}\text { Seção IV - Identificação dos membros da } \\
\text { família }\end{array}$ & $\begin{array}{l}\text { Apresenta os nomes dos integrantes da família, idade, } \\
\text { sexo, e a posição dos mesmos nas famílias frente ao seu } \\
\text { responsável. }\end{array}$ \\
\hline $\begin{array}{l}\text { Seção V - Posição na família, estado civil e } \\
\text { atividades profissionais }\end{array}$ & $\begin{array}{l}\text { Caracteriza a posição da família no que se refere a estado } \\
\text { civil, situação dos vínculos empregatícios e atividades que } \\
\text { geram renda para a família. Fornece informações do } \\
\text { responsável pela família sobre o tempo de moradia em } \\
\text { Cuiabá, no bairro e naquele domicilio. }\end{array}$ \\
\hline $\begin{array}{l}\text { Seção VI - Informações sobre portadores de } \\
\text { necessidades especiais na família }\end{array}$ & $\begin{array}{l}\text { Reconhece a existência e a quantidade de portadores de } \\
\text { necessidades especiais. Além disso, elenca quais os tipos } \\
\text { de necessidade especiais encontradas entre os membros } \\
\text { da família. }\end{array}$ \\
\hline Seção VII - Características do domicílio & $\begin{array}{l}\text { Cita detalhadamente as características do domicilio, e } \\
\text { possibilita saber se o imóvel é próprio, alugado ou cedido. } \\
\text { Além disso, fornece informações sobre as características } \\
\text { gerais da casa, como materiais utilizados, tipo da } \\
\text { residência, serviços públicos utilizados pela residência. }\end{array}$ \\
\hline $\begin{array}{l}\text { Seção VIII - Avaliação das redes de } \\
\text { parentesco e relações sociais no circuito do } \\
\text { bairro e da vizinhança }\end{array}$ & $\begin{array}{l}\text { Descreve as relações de parentesco e vizinhança no } \\
\text { bairro, associando os respectivos nome e endereço e as } \\
\text { formas e intensidade que permeiam os relacionamentos. }\end{array}$ \\
\hline $\begin{array}{l}\text { Seção IX - Grau de importância dos } \\
\text { equipamentos urbanos e dos problemas do } \\
\text { bairro onde mora }\end{array}$ & $\begin{array}{l}\text { Assinala três informações importantes: quais os serviços } \\
\text { mais importantes para o entrevistado; quais as opções de } \\
\text { lazer; e quais os problemas que ele considera mais sérios } \\
\text { no bairro onde mora. As referidas questões foram } \\
\text { apresentadas em forma de disco com o objetivo de não } \\
\text { influenciar a resposta do entrevistado, assim o } \\
\text { entrevistado valorava a sua escolha, sendo que a mais } \\
\text { importante recebia a numeração } 1 \text {. }\end{array}$ \\
\hline $\begin{array}{l}\text { Seção X - Características e custos com a } \\
\text { educação de cada membro da família }\end{array}$ & $\begin{array}{l}\text { Registra o grau de escolaridade, utilização de instituições } \\
\text { de ensino e custos com escolaridade do responsável e } \\
\text { demais membros residentes no domicílio. }\end{array}$ \\
\hline $\begin{array}{l}\text { Seção XI - Rendimentos individuais de cada } \\
\text { membro da família originados de } \\
\text { rendimentos de trabalho e de benefícios } \\
\text { sociais pagos pelo governo }\end{array}$ & $\begin{array}{l}\text { Destaca os rendimentos individuais, podendo ser de } \\
\text { benefícios como seguro desemprego, aposentadoria, } \\
\text { pensão alimentícia, aluguel entre outros. }\end{array}$ \\
\hline $\begin{array}{l}\text { Seção XII - Rendimentos da família } \\
\text { originados de outros benefícios sociais pagos }\end{array}$ & $\begin{array}{l}\text { Mostra os rendimentos totais da família derivados de } \\
\text { benefícios como bolsa família; vale gás e outros benefícios }\end{array}$ \\
\hline
\end{tabular}




\begin{tabular}{|l|l|}
\hline pelo governo & pagos pelo governo. \\
\hline $\begin{array}{l}\text { Seção XIII - Gastos relacionados ao } \\
\text { domicilio e à família }\end{array}$ & $\begin{array}{l}\text { Informa os gastos diversos da família fornecidos pelo } \\
\text { responsável pelo domicilio. }\end{array}$ \\
\hline $\begin{array}{l}\text { Seção XIV - Total dos rendimentos e das } \\
\text { despesas da família }\end{array}$ & $\begin{array}{l}\text { Estabelece a soma dos rendimentos e a soma das } \\
\text { despesas da família. }\end{array}$ \\
\hline Seção XV - Patrimônio histórico e cultural & $\begin{array}{l}\text { Sintetiza a percepção do entrevistado em relação aos } \\
\text { aspectos históricos e culturais do bairro e sua } \\
\text { importância. }\end{array}$ \\
\hline $\begin{array}{l}\text { SEÇãO XVI - Nível de preocupação com om onanamento, confiança política e e } \\
\text { institucional }\end{array}$ & $\begin{array}{l}\text { Apresenta o nível de preocupação do responsável com o } \\
\text { remanejamento e confiança política. Nesta seção, há } \\
\text { pergunta aberta com descrição fiel do discurso do } \\
\text { entrevistado. }\end{array}$ \\
\hline
\end{tabular}

Quadro 1 - Identificação e objetivo-características das seções do instrumento de pesquisa

Optou-se pelas questões fechadas com possibilidade de respostas numéricas, a fim de facilitar o armazenamento das informações no banco de dados. Foi utilizada apenas uma pergunta aberta, cuja resposta foi transcrita com as palavras do entrevistado, considerada de cunho geral e abrangente para traduzir a problemática em questão, assim perguntou-se: "Quais são as suas preocupações com a construção da Avenida Parque do Barbado?".

Nos quatro bairros todos os domicílios foram visitados e os habitantes entrevistados. Na Figura 2 pode ser visualizado um exemplo de uma parte da área de estudos e a cobertura espacial realizada, nas duas margens do Córrego do Barbado.

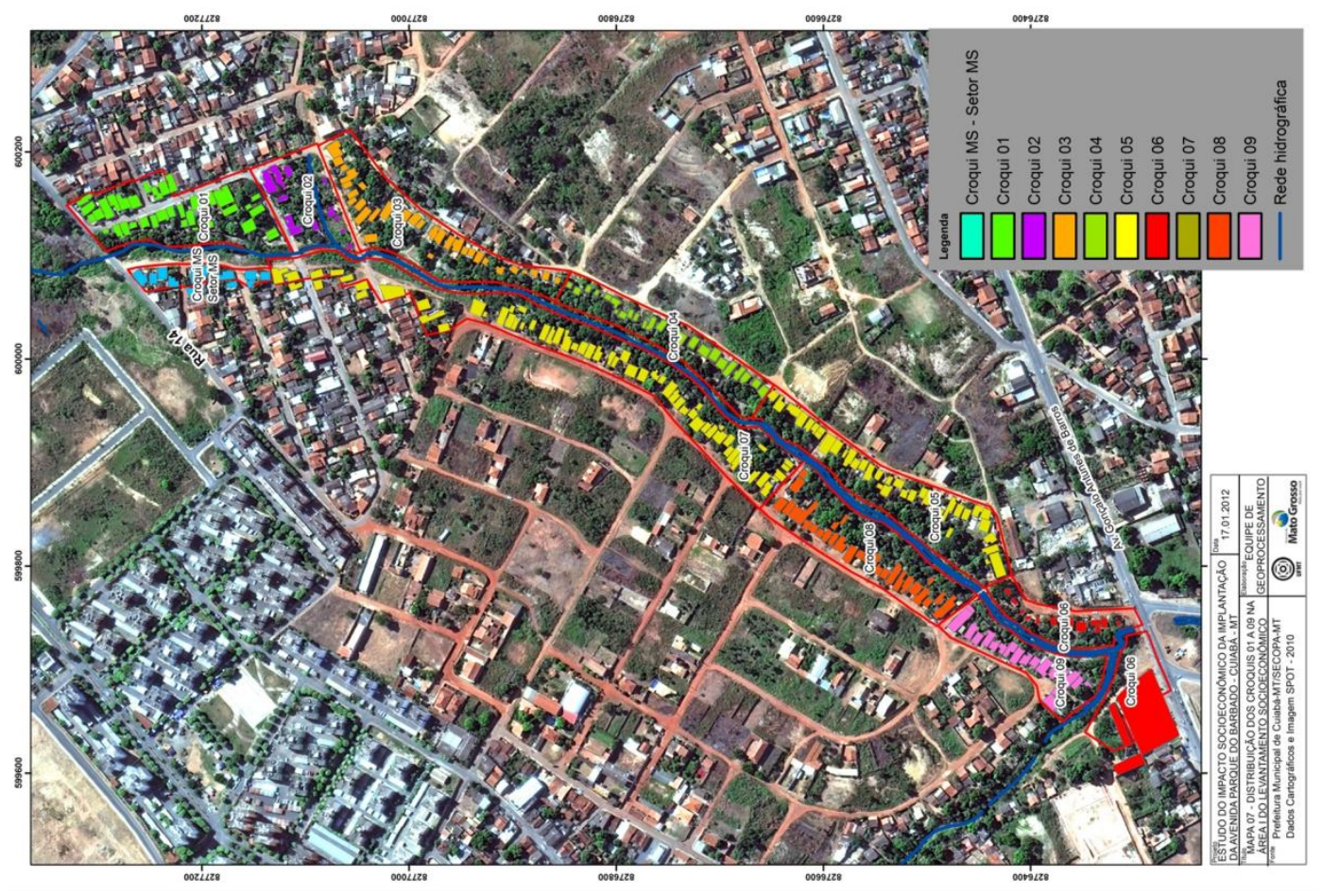

Figura 2 - Exemplo da cobertura da área onde foram aplicadas as entrevistas.

\section{MARCO CONCEITUAL}

Os desastres naturais constituem um dos graves problemas que afetam a sociedade moderna causando severos danos socioeconômicos e ambientais. Vários estudos mostram o conceito de vulnerabilidade e de suscetibilidade como sinônimos face aos eventos dos desastres naturais. Entretanto, a vulnerabilidade está relacionada mais aos aspectos humanos e socioeconômicos e a susceptibilidade aos aspectos estrutural ou físico (ZAMPARONI e NUNES, 2012). 


\section{ISSN: 1980-055x (Impressa) 2237-8642 (Eletrônica)}

A produção de conhecimento sobre as vulnerabilidades da população e a suscetibilidade de um local, em relação a condições atmosféricas, em especial, às mudanças climáticas tem estreita relação com a formulação e implementação de políticas públicas.

As discussões sobre as mudanças climáticas na escala de abordagem global conjugam uma diversidade enorme de opiniões que compõe os pontos e contrapontos, em especial quanto à sua derivação antrópica e/ou natural. Neste contexto um dos maiores desafios da atualidade é o enfrentamento dos desastres naturais urbanos.

A UNISDR (2009) define desastre natural como perturbação do funcionamento de uma sociedade que envolve perdas humanas, materiais, econômicas e ambientais de enorme extensão, com impactos que excedem a capacidade da sociedade afetada de arcar com seus próprios recursos.

Para Annan (2006) os riscos naturais são parte da vida, porém se transformam em catástrofes quando há perdas de vidas humanas e os meios de subsistência são atingidos. Ele salienta ainda que "as comunidades são cada vez mais vulneráveis, devido às atividades humanas que conduzem a um aumento da pobreza, a uma maior densidade populacional nas cidades, à degradação do ambiente e à aceleração das alterações climáticas".

Pinto, (2007) afirma queo conceito de risco (risk) corresponde à quantificação da circunstância ou da situação de risco natural. Evento (events) corresponde ao processo atmosférico ou geológico que tenha ocorrido sem causar conseqüênciasócioeconômica; Desastre (disaster) quando causa danos sócio-econômicos, pois é uma ruptura extrema de funcionamento de uma sociedade que gera perdas de vidas humanas, materiais e danos ao meio ambiente em grande escala, que superam a capacidade da sociedade afetada para fazer frente a situação utilizando unicamente seus próprios recursos; Perigo (hazard) refere-se a circunstância ou situação de perigo, perda ou dano, social e econômico, devido a uma condição geológica ou atmosférica, ou a uma probabilidade de ocorrência de processos naturais, induzido ou não.

Entre os principais agravantes antrópicos, relacionados aos desastres naturais encontramos, entre outros, as chuvas ácidas, derivadas das emissões de gases nocivos; as inundações resultantes da impermeabilização do solo e ausência de infraestrutura na cidade e da retirada da mata ciliar e assoreamento dos rios; os escorregamentos de massa resultantes da ocupação desordenada de encostas íngremes.

Os componentes físicos de uma área geográfica só podem ser entendidos à luz dos feitos de uma sociedade, inseridos em um processo histórico determinado. Assim, analisar o ambiente urbano significa considerar, além de outros fatores, os conflitos socioambientais existentes nessas áreas.

No Brasil, normatizações nas esferas federal, estadual e municipal rezam que parte das áreas urbanas deve manter sua vegetação natural protegida, entretanto, muitas vezes, são ocupadas por assentamentos humanos informais. A situação atinge hoje níveis insustentáveis em muitas das cidades brasileiras. Estima-se que mais de um milhão de pessoas vivem em áreas que deveriam ter pouca ou nenhuma ocupação por força da legislação de proteção de mananciais.

As APP's existentes às margens desses espelhos d'água urbanos têm sido, ao longo dos anos, fortemente alteradas, perdendo suas características naturais em função de um crescimento urbano muitas vezes desordenado, sendo necessária uma análise quanto ao cumprimento de seu papel, função e importância, ainda na forma como haviam sido criadas e protegidas através da legislação ambiental. Atualmente, pelo menos um milhão de pessoas vive em áreas de APP, na maioria população de baixa renda que não consegue ter acesso à moradia nas áreas urbanas legais, com infraestrutura adequada e preço acessível (SERVILHA, 2006).

A informalidade, ou clandestinidade, existente no ambiente urbano desafia a gestão pública da cidade, contudo impele à necessidade cada vez maior de integração das diferentes políticas públicas, em especial as relativas à natureza e à sociedade. Sob este aspecto, destaca-se a importância da gestão ambiental urbana. 
A regularização das situações clandestinas poderá permitir ao Poder Público exigir ou promover melhorias nas condições de habitabilidade e, consequentemente, de qualidade das águas dos cursos d'águas investigados.

Torna-se necessário sensibilizar a sociedade sobre a importância de se preservarem as matas ciliares, divulgando as diretrizes legais que versam sobre a sua preservação, impondo sanções aos infratores, em especial multa, e obrigando a restaurar áreas degradadas, como prescreve o art. 26 do Código Florestal (Lei No. 4.771, de 15 de setembro de 1965) (BRASIL, 1965), a Lei Federal No. 9.605 de 12 de fevereiro de 1998 (BRASIL, 1998), e o Decreto No. 3.179 de 21 de setembro de 1999 (BRASIL, 1999).

Entretanto, os limites entre o processo de urbanização e a relação com a preservação ambiental merecem ser alvos de intensa reflexão, especialmente com relação às APP que são as faixas marginais aos corpos d'água, cuja regra é a intocabilidade (ARAÚjO, 2002), admitida excepcionalmente a supressão da vegetação apenas em casos de utilidade pública ou interesse social legalmente previsto (Resolução CONAMA 369/2006).

Embora o regime legal de proteção das APP seja bastante rígido, as diversas restrições previstas na legislação ambiental e que regulamentam a proteção das APP - Constituição Federal (Art. 225; 1988), Código Florestal (Lei n. 4.711/65), Resolução CONAMA 369 (2006), e regulamentações municipais têm se mostrado ineficazes no contexto do uso do solo, em especial em áreas urbanas.

As áreas em foco no presente estudo, possuem relação muito próxima à ideia de periferia devido ao crescimento do espaço urbano de Cuiabá, desde a década de 1970. Após o deslocamento dos moradores das áreas centrais para a região da Morada da Serra, o vazio de espaços em seu intervalo originou, entre as centralidades, novos espaços de moradias irregulares às margens do Córrego Barbado. Os trabalhadores buscavam pelos espaços de moradias nos arredores, em áreas mais distantes e por isso, desvalorizadas. Mas, com o crescimento da cidade, áreas carentes se encontram atualmente ilhadas por áreas dotadas de infraestrutura em áreas centrais.

Segundo Moura, Ultramari (1996), periferia pode ser definida como lugar afastado de algum ponto central. Urbanisticamente, periferias são áreas com baixa ocupação do solo, porém com uma alta expansão para áreas novas e mais longínquas. Esse novo traçado urbano aumenta o custo ao poder público, pois terá que estender as redes de infraestrutura básica e com isso iniciar um estado de carências, que é característico das áreas periféricas, soma-se às distâncias físicas, a distância social de sua qualidade de vida.

Abrangendo ainda o contexto atual das grandes cidades, pode-se ainda classificar as periferias em ricas ou pobres, ou ainda periferia geográfica - que se relaciona a lugares distantes das áreas consideradas centrais - que pode ser rica e pobre ou periferia social, onde a vulnerabilidade das pessoas geralmente é maior.

De acordo com Maricato (2001), as periferias urbanas são áreas de concentração de moradias de população de baixa renda, carente dos serviços básicos essenciais que, consequentemente, sofre os efeitos dos longos deslocamentos para o trabalho, o consumo e o lazer, vivendo num sistema de autoconstrução que se reproduz ao produzir casas em lugares sem infraestrutura e com um sobre-trabalho individual em que as condições gerais de reprodução do espaço urbano são ruins.

O Estado, ao assumir o papel de gestor urbano, tem o poder de reverter essa condição de vida nas áreas periféricas, utilizando o planejamento como uma ferramenta de gestão que pode levar à modernização dos serviços urbanos, fazendo com que cada vez mais a população da cidade tenha acesso a esses recursos.

A inclusão daqueles moradores sem renda, sem acesso ao mercado de trabalho, e ainda, de acordo com Matias (2004), daqueles que não têm acesso a bens e serviços públicos, assim 
como segurança, justiça social e a cidadania, se faz necessária, pois tais pessoas estão vulneráveis socialmente, ou seja, excluídas de compor a malha de habitação segura, de ter acesso ao saneamento básico, à educação e até bens considerados supérfluos como os equipamentos culturais (teatro e cinema), benfeitorias que são direitos de todos os cidadãos.

Para este estudo adotou-se os critérios e as definições utilizadas pelo Instituto Brasileiro de Geografia e Estatística - IBGE, no Censo Demográfico 2010, com algumas adaptações à realidade pesquisada.

Assim, o termo domicílio significa o local estruturalmente separado e independente que se destina a servir de habitação a uma ou mais pessoas, ou que esteja sendo utilizado como tal, assim, considera-se como domicilio a casa e o terreno. As ocupações irregulares caracterizamse pela presença de mais de um domicilio em um mesmo terreno, haja vista a inexistência de cercas ou muros, ou seja, as casas são contínuas e até mesmo geminadas. Dessa forma, o critério de separação por paredes, muros ou cercas e cobertos por um teto define a existência de mais de um domicilio em uma mesma propriedade ou terreno.

O domicilio unifamiliar apresenta uma única família residindo em uma única casa, já o domicilio multifamiliar é o local de moradia de mais de uma família, vivem na mesma casa sem paredes para separar as famílias e o relacionamento entre os seus ocupantes é ditado por parentesco, por dependência econômica ou por normas de convivência. Existem outras modalidades de domicílios multifamiliares, entre eles a casa de cômodos ou cortiço, com subdivisões de habitações em uma mesma edificação, isto é, com várias famílias diferentes, apresentando as seguintes características: uso comum de instalações hidráulicas e sanitárias (banheiro, tanque, cozinha etc.), uso do mesmo ambiente para diversas funções (cozinhar, fazer refeições, trabalhar, entre outros) São geralmente alugadas, subalugadas ou cedidas, e sem contrato formal de locação.

\section{ANÁLISE E DISCUSSÃO DOS RESULTADOS}

O diagnóstico socioeconômico mostrou que, ao longo do percurso delimitado para a construção da Avenida Parque do Barbado, serão impactadas aproximadamente 579 famílias, o que envolve cerca de 1695 pessoas que residem em 445 casas, contudo foram realizadas apenas 499 entrevistas (Tabela 1).

\begin{tabular}{|l|l|l|}
\hline BAIRROS & TOTAL DE FAMÍLIAS & $\begin{array}{l}\text { TOTAL DE CASAS } \\
\text { (Domicílios) }\end{array}$ \\
\hline BELA VISTA & 113 & 82 \\
\hline CASTELO BRANCO & 220 & 180 \\
\hline PEDREGAL & 122 & 96 \\
\hline RENASCER & 70 & 54 \\
\hline MS DO CROQUI & 37 & 20 \\
\hline SETOR MS- CROQUI MS & 17 & 13 \\
\hline TOTAL & 579 & 445 \\
\hline
\end{tabular}

Tabela 1- Total de famílias, entrevistas e Total de domicílios - Bairros Bela Vista, Castelo Branco, Pedregal, Renascer, MS do Croqui e Setor MS Croqui MS.

Fonte: Autodeclaração dos entrevistados

O número de famílias corresponde a todas as famílias declaradas durante a entrevista, porém não corresponde ao número de entrevistas realizadas com êxito (Tabela 2). Foram consideradas as 
famílias declaradas pelas pessoas que atenderam ao chamado do coletor de dados e responderam a primeira pergunta do instrumento de pesquisa (formulário): "quantas famílias moram aqui?". Ocorreram casos em que o respondente informou o número de famílias, porém a entrevista não foi realizada com todas as famílias informadas, haja vista que, mesmo por sucessivas tentativas em dias e horários diferenciados, o responsável pela família.

\begin{tabular}{|l|l|l|l|}
\hline ENTREVISTAS REALIZADAS COM ÊXITO \\
\hline BAIRROS & No croqui & MS & TOTAL \\
\hline BELA VISTA & 97 & 28 & 125 \\
\hline CASTELO BRANCO & 206 & 00 & 206 \\
\hline PEDREGAL & 103 & 8 & 111 \\
\hline RENASCER & 56 & 1 & 57 \\
\hline TOTAL & $\mathbf{4 6 2}$ & $\mathbf{3 7}$ & $\mathbf{4 9 9}$ \\
\hline
\end{tabular}

Tabela 2 - Entrevistas realizadas com êxito

Fonte: Croquis de Campo

Evidencie-se que o número de entrevistas realizadas com êxito é diferente por bairro, assim as comparações não são possíveis em todas as temáticas investigadas pelo instrumento de pesquisa. O número de domicílios (casas) não corresponde ao número de entrevistas e nem ao número de famílias, pois, em alguns casos, há mais de uma família morando na mesma casa (domicílio). Foram realizadas de três a quatro tentativas para efetivar as entrevistas, contudo, 80 entrevistas não foram realizadas, devido à recusa, domicilio fechado ou vago e outros motivos (Tabela 3). Sendo assim, durante o processo de remanejamento o número de famílias e casas pode ser diferente do apresentado nesse documento já que não foi possível identificar o número de famílias nos casos dos domicílios que se encontravam fechados ou vagos.

\begin{tabular}{|l|c|c|c|l|}
\hline \multirow{2}{*}{ BAIRROS } & \multicolumn{4}{|c|}{ MOTIVOS } \\
\cline { 2 - 5 } & Recusa & $\begin{array}{c}\text { Domicilio fechado } \\
\text { ou vago }\end{array}$ & Outros motivos & Total por bairro \\
\hline BELA VISTA & 2 & 7 & 7 & 16 \\
\hline CASTELO BRANCO & 0 & 4 & 10 & 14 \\
\hline PEDREGAL & 1 & 9 & 9 & 19 \\
\hline RENASCER & 1 & 11 & 2 & 14 \\
\hline MS DO CROQUI & 0 & 1 & 15 & 16 \\
\hline $\begin{array}{l}\text { SETOR MS - CROQUI } \\
\text { MS }\end{array}$ & 0 & 1 & 0 & 1 \\
\hline TOTAL & 4 & 33 & 43 & 80 \\
\hline
\end{tabular}

Tabela 3 - Motivos da não realização das entrevistas nos Bairros Bela Vista, Castelo Branco, Pedregal e Renascer

Fonte: Croquis de Campo

Nas entrevistas também foi investigado o total de famílias locatárias (inquilinos) de imóveis nos bairros, além dos respectivos locadores (proprietários). (Tabela 4). 


\begin{tabular}{|l|c|c|}
\hline \multicolumn{3}{|c|}{ FAMÍLIAS LOCADORAS E LOCATÁRIAS DE IMÓVEIS } \\
\hline \multicolumn{1}{|c|}{ BAIRRO } & LOCADOR & LOCATÁRIO \\
\hline BELA VISTA & 13 & 22 \\
\hline CASTELO BRANCO & 10 & 9 \\
\hline PEDREGAL & 5 & 10 \\
\hline RENASCER & 12 & 13 \\
\hline MS DO CROQUI & 0 & 15 \\
\hline SETOR MS & 0 & 0 \\
\hline TOTAL & 40 & 69 \\
\hline
\end{tabular}

Tabelas 4 - Imóveis Locados nos Bairros Belas Vista, Castelo Branco, Pedregal e Renascer Fonte: Autodeclaração dos Entrevistados;

Diante do exposto, a construção da referida avenida impactará aproximadamente 579 famílias conforme foi registrado nesta pesquisa, cujo perfil e condições gerais serão apresentados a seguir.

\section{Perfil das famílias e laços de parentesco}

A família, como referencial analítico, é considerada em duas modalidades: família mononuclear, composta por pai, mãe e filhos; e família extensa, composta pelos membros da família mononuclear além de netos, avós, tios e outros. Em tais dimensões, a família é capaz de expressar o perfil da população de determinado espaço geográfico e, ao adotá-la como referência, pode otimizar o entendimento de situações peculiares de organização e convívio social. O número médio de membros por família dos bairros que constituem a área da pesquisa está apresentado na figura 5.

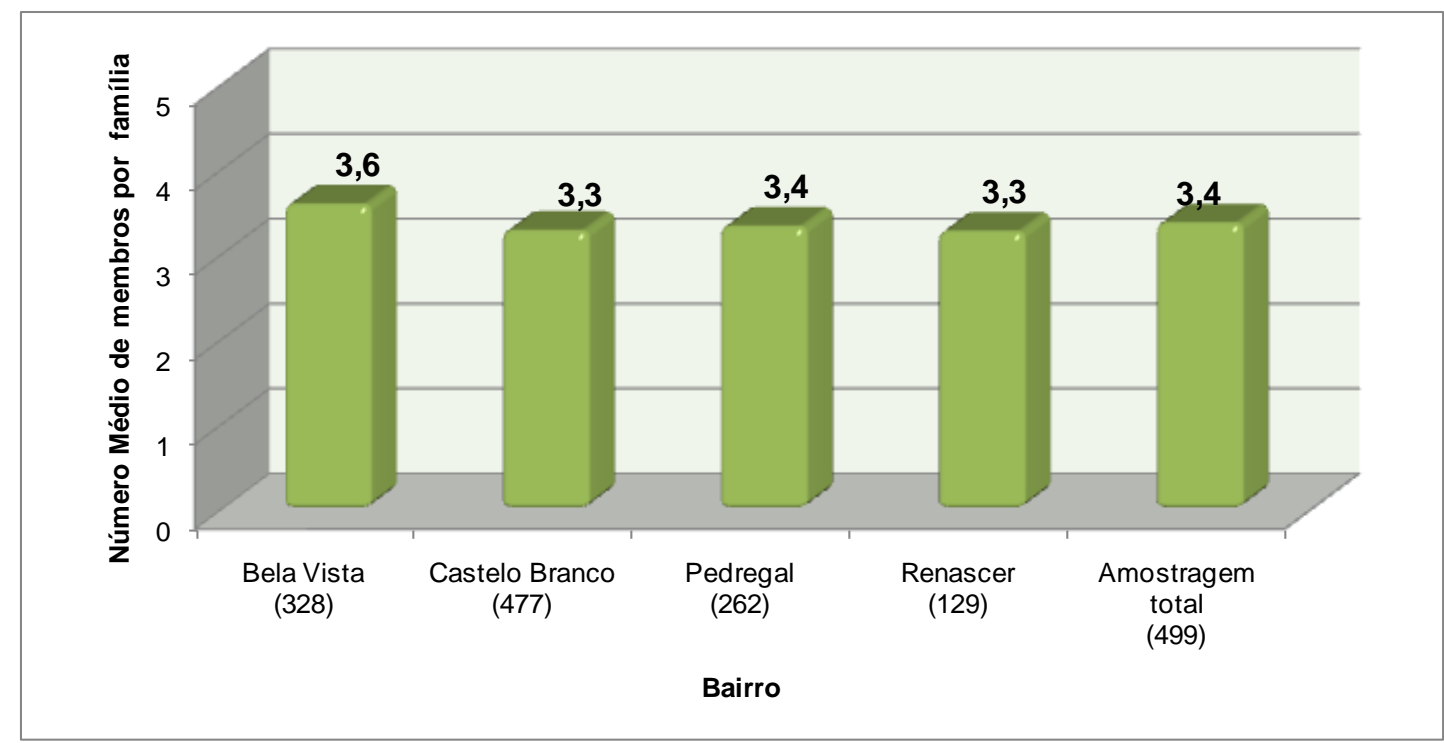

Figura 5- Número Médio de Membros por Família Bairros Bela Vista, Castelo Branco, Pedregale Renascer - Cuiabá/MT

Fonte: Autodeclaração dos Entrevistados 
Os grupos familiares integrantes do universo da pesquisa são estruturados em função do gênero feminino/masculino. As entrevistas realizadas com êxito (499) nos quatro bairros apontam um percentual maior do sexo feminino 263 (52,7\%) como responsáveis pela família, com destaque para o Castelo Branco com 109 (52,9\%) pessoas do sexo feminino. Talvez, devido à diferença dos números de entrevistas realizadas em cada bairro, o Renascer apresenta $64(57,7 \%)$ mulheres responsáveis pela família.

No que se refere ao estado civil da população entrevistada, identificou-se que $35,7 \%$ são casadas, seguido de $27,1 \%$ solteiros e $24,2 \%$ que mantêm união estável, os quais correspondem a 178, 135 e 121 pessoas, respectivamente. O percentual restante se divide nas categorias desquitado, divorciado e viúvo. Deste cômputo, a maior porcentagem de casadas foi identificada no bairro Bela Vista, onde $52(41,9 \%)$ e $24(42,1 \%)$ das entrevistadas se declararam casados.

Constatou-se que em $90,5 \%$ das moradias existem quintais e estes são utilizados para diferentes finalidades. Destacam-se os "ambientes de lazer" com 45,1\% seguido dos espaços destinados aos pomares com 18,2\%. Observou-se em campo que os quintais são utilizados para mais de uma opção, muitas vezes passam a ser "extensão das moradias", onde se realizam serviços domésticos de lavagem e secagem de roupas, além de serem utilizados como garagem e depósitos de material de construção e sucatas. Tais espaços são pouco utilizados como locais de trabalho, apenas 3,5\%, entretanto os quintais contribuem para subsistência da família por meio da sua utilização com plantio para uso próprio $(6,1 \%)$ e criação de pequenos animais $(9,1 \%)$. (Tabela 5$)$

\begin{tabular}{|c|c|c|c|c|c|c|c|c|c|c|c|c|c|c|}
\hline \multirow[t]{2}{*}{$\begin{array}{l}\text { Dom icílios com ou sem quintal e tipos } \\
\text { de utilização do quintal }\end{array}$} & \multicolumn{2}{|c|}{ Bela Vista } & \multicolumn{2}{|c|}{$\begin{array}{l}\text { Castelo } \\
\text { Branco }\end{array}$} & \multicolumn{2}{|c|}{ Pedregal } & \multicolumn{2}{|c|}{ Renascer } & \multicolumn{2}{|c|}{$\begin{array}{l}\text { Ms do } \\
\text { croqui }\end{array}$} & \multicolumn{2}{|c|}{$\begin{array}{c}\text { Croqui Ms } \\
\text { Setor Ms }\end{array}$} & \multicolumn{2}{|c|}{ Total } \\
\hline & $\mathrm{N}$ & $\%$ & $\mathrm{~N}$ & $\%$ & $\mathrm{~N}$ & $\%$ & $\mathrm{~N}$ & $\%$ & $\mathrm{~N}$ & $\%$ & $\mathrm{~N}$ & $\%$ & $\mathbf{N}$ & $\%$ \\
\hline \multicolumn{15}{|l|}{ Existência de quintal no domicílio } \\
\hline Sim & 71 & 88,8 & 162 & 91,0 & 91 & 94,8 & 46 & 85,2 & 18 & 90,0 & 11 & 84,6 & 399 & 90,5 \\
\hline Não & 9 & 11,3 & 16 & 9,0 & 5 & 5,2 & 8 & 14,8 & 2 & 10,0 & 2 & 15,4 & 42 & 9,5 \\
\hline Dados ausentes & 2 & & 2 & & 0 & & 0 & & 0) & & 0 & & 4 & \\
\hline Total & 82 & 100,0 & 180 & 100,0 & 96 & 100,0 & 54 & 100,0 & 20 & 100,0 & 13 & 100 & 445 & 100 \\
\hline \multicolumn{15}{|l|}{ Utilização do quintal do dom icílio } \\
\hline Horta & 0 & 0,0 & 11 & 7,6 & 6 & 5,6 & 3 & 6,8 & 0 & 0,0 & 0 & 0,0 & 20 & 5,1 \\
\hline Pomar & 15 & 21,4 & 29 & 20,0 & 19 & 17,8 & 9 & 20,5 & 0 & 0,0 & 0 & 0,0 & 72 & 18,2 \\
\hline Lazer & 38 & 54,3 & 64 & 44,1 & 43 & 40,2 & 15 & 34,1 & 12 & 66,7 & 6 & 54,5 & 178 & 45,1 \\
\hline Local de trabalho & 3 & 4,3 & 4 & 2,8 & 2 & 1,9 & 5 & 11,4 & 0 & 0,0 & 0 & 0,0 & 14 & 3,5 \\
\hline Jardim & 0 & 0,0 & 2 & 1,4 & 1 & 0,9 & 0 & 0,0 & 0 & 0,0 & 0 & 0,0 & 3 & 0,8 \\
\hline Criação de pequenos animais & 7 & 10,0 & 10 & 6,9 & 9 & 8,4 & 2 & 4,5 & 6 & 33,3 & 2 & 18,2 & 36 & 9,1 \\
\hline Plantio para uso próprio & 5 & 7,1 & 11 & 7,6 & 3 & 2,8 & 2 & 4,5 & 0 & 0,0 & 3 & 27,3 & 24 & 6,1 \\
\hline Plantio para comercialização & 1 & 1,4 & 2 & 1,4 & 1 & 0,9 & 0 & 0,0 & 0 & 0,0 & 0 & 0,0 & 4 & 1,0 \\
\hline Outro & 1 & 1,4 & 12 & 8,3 & 4 & 3,7 & 4 & 9,1 & 0 & 0,0 & 0 & 0,0 & 21 & 5,3 \\
\hline Mais de uma opção & 0 & 0,0 & 0 & 0,0 & 19 & 17,8 & 4 & 9,1 & 0 & 0,0 & 0 & 0,0 & 23 & 5,8 \\
\hline Dados ausentes & 1 & & 17 & & 4 & & 2 & & 0 & & 0 & & 24 & \\
\hline Total & 71 & 100 & 162 & 100,0 & 111 & 100,0 & 46 & 100,0 & 18 & 100 & 11 & 100 & 419 & 100 \\
\hline
\end{tabular}

Tabela 5 - Total de Domicílios com ou Sem Quintal e Tipos de Utilização dos Quintais por Bairro -Bairros Bela Vista, Castelo Branco, Pedregal, Renascer, Setor MS e Croqui MS - Cuiabá/MT

Fonte: Autodeclaração dos entrevistados

\section{Infraestrutura Urbana}

Os Bairros da Bela Vista, Castelo Branco, Pedregal e Renascer estão localizados em regiões nobres do espaço urbano de Cuiabá, contudo, algumas de suas características aproximam das paisagens das áreas periféricas, locais em que a população de menor renda tem acesso à posse do solo urbano. Dessa forma este item busca traçar um quadro das características da infraestrutura urbana em relação aos domicílios que integram o universo da pesquisa.

A origem da água que a população da área impactada utiliza para beber pode ser visualizada na Tabela 6 . Os dados revelam que $50,9 \%$ utilizam água filtrada; $25,7 \%$ mineral e $18,6 \%$ da torneira sem filtro. O percentual restante se insere na opção da água fervida. 


\begin{tabular}{|c|c|c|c|c|c|c|c|c|c|c|c|c|c|c|}
\hline \multirow[t]{2}{*}{$\begin{array}{l}\text { Água usada para } \\
\text { beber no domicílio }\end{array}$} & \multicolumn{2}{|c|}{ Bela Vista } & \multicolumn{2}{|c|}{$\begin{array}{l}\text { Castelo } \\
\text { Branco }\end{array}$} & \multicolumn{2}{|c|}{ Pedregal } & \multicolumn{2}{|c|}{ Renascer } & \multicolumn{2}{|c|}{$\begin{array}{l}\text { Ms do } \\
\text { croqui }\end{array}$} & \multicolumn{2}{|c|}{$\begin{array}{l}\text { Croqui Ms } \\
\text { Setor Ms }\end{array}$} & \multicolumn{2}{|c|}{ Total } \\
\hline & $\mathrm{N}$ & $\%$ & $\mathrm{~N}$ & $\%$ & $\mathrm{~N}$ & $\%$ & $\mathrm{~N}$ & $\%$ & $\mathrm{~N}$ & $\%$ & $\mathrm{~N}$ & $\%$ & $\mathrm{~N}$ & $\%$ \\
\hline Filtrada & 41 & 42,3 & 111 & 53,9 & 49 & 47,6 & 29 & 51,8 & 15 & 71,4 & 9 & 56,3 & 254 & 50,9 \\
\hline Fervida & 7 & 7,2 & 10 & 4,9 & 4 & 3,9 & 1 & 1,8 & 0 & 0,0 & 2 & 12,5 & 24 & 4,8 \\
\hline Mineral & 35 & 36,1 & 37 & 18,0 & 34 & 33,0 & 15 & 26,8 & 4 & 19,0 & 3 & 18,8 & 128 & 25,7 \\
\hline Direto da torneira & 14 & 14,4 & 48 & 23,3 & 16 & 15,5 & 11 & 19,6 & 2 & 9,5 & 2 & 12,5 & 93 & 18,6 \\
\hline Dados ausentes & 16 & & 14 & & 19 & & 14 & & 16 & & 1 & & 80 & \\
\hline Total & 113 & 100,0 & 220 & 100,0 & 122 & 100,0 & 70 & 100,0 & 37 & 100,0 & 17 & 100,0 & 579 & 100,0 \\
\hline
\end{tabular}

Tabela 6 - Tipo Água usada para beber no domićlio Bairros Bela Vista, Castelo Branco, Pedregal, Renascer, Setor MS e Croqui MS - Cuiabá/MT

Fonte: Autodeclaração dos entrevistados

No tocante à procedência da água utilizada, $86 \%$ da população da área impactada declarou que a rede de água de Cuiabá (SANECAP) constitui a fonte de abastecimento principal do domicílio e que o abastecimento é feito com regularidade média aproximada de 6 dias por semana. Para um percentual menor de entrevistados, as opções se dividem em uso do poço, cisterna, água do vizinho, gambiarra, entre outros.

Aproximadamente $100 \%$ dos entrevistados afirmam utilizar energia elétrica, fornecida pela CEMAT, como a principal fonte de iluminação dos domicílios. No que se refere ao combustível usado para o preparo dos alimentos, predomina o uso do gás de botijão.

Apresenta índices consideráveis em relação a importância de postos de saúde para os entrevistados do Bairro Bela Vista $(2,9 \%)$ e Castelo Branco $(2,1)$ e asfalto para os moradores do Bairro Pedregal (3,6\%).

\section{Nível educacional das famílias e informações sobre os portadores de necessidades especiais - PNE}

As informações desta seção sintetizam o quadro educacional e apresentam informações sobre os portadores de necessidade especiais (PNE) das famílias entrevistadas. De acordo com as informações da Tabela 7, no universo de 499 responsáveis pela família, 443 declararam não frequentar a escola, ou seja, $89,3 \%$ do total. Quando questionados sobre os motivos da não frequência, $45,8 \%$ mencionaram a necessidade de trabalhar para garantir o sustento familiar como o principal argumento, o percentual de 2,9\% se repetiu nos quesitos: custo elevado das mensalidades e ajudar os pais. Apenas 2,5\% colocaram como causa a ausência de escolas nas proximidades. Observou-se muita dificuldade para explicitar a causa da não frequência escolar, haja vista que $46 \%$ deles não souberam esclarecer os motivos. Dos responsáveis pela família que não frequentam as unidades escolares, $44,7 \%$ possuem o Nível Fundamental incompleto e 22,3\% concluíram o Ensino Médio. 


\begin{tabular}{|c|c|c|c|c|c|c|c|c|c|c|}
\hline \multirow{2}{*}{$\begin{array}{l}\text { Frequência à escola, motivo da não } \\
\text { frequência e nível de escolaridade do } \\
\text { responsável pela família }\end{array}$} & \multicolumn{2}{|c|}{ Bela Vista } & \multicolumn{2}{|c|}{$\begin{array}{l}\text { Castelo } \\
\text { Branco }\end{array}$} & \multicolumn{2}{|c|}{ Pedregal } & \multicolumn{2}{|c|}{ Renascer } & \multicolumn{2}{|c|}{ Total } \\
\hline & $\mathrm{N}$ & $\%$ & $\mathrm{~N}$ & $\%$ & $\mathrm{~N}$ & $\%$ & $\mathrm{~N}$ & $\%$ & $\mathrm{~N}$ & $\%$ \\
\hline \multicolumn{11}{|l|}{ Frequência à escola } \\
\hline Sim & 15 & 12,1 & 19 & 9,3 & 13 & 10,5 & 6 & 10,5 & 53 & 10,7 \\
\hline Não & 109 & 87,9 & 185 & 90,7 & 98 & 89,5 & 51 & 89,5 & 443 & 89,3 \\
\hline Dados ausentes & 1 & & 2 & & 0 & & 0 & & 3 & \\
\hline Total & 125 & 100,0 & 206 & 100,0 & 111 & 100,0 & 57 & 100,0 & 499 & 100,0 \\
\hline \multicolumn{11}{|l|}{ Motivo da não frequência } \\
\hline Trabalho & 46 & 42,2 & 93 & 50,3 & 36 & 36,7 & 28 & 54,9 & 203 & 45,8 \\
\hline Não há escolas nas proximidades & 5 & 4,6 & 6 & 3,2 & 0 & 0,0 & 0 & 0,0 & 11 & 2,5 \\
\hline Custo elevado das mensalidades & 3 & 2,8 & 5 & 2,7 & 5 & 5,1 & 0 & 0,0 & 13 & 2,9 \\
\hline Outros & 54 & 49,5 & 75 & 40,5 & 52 & 53,1 & 22 & 43,1 & 203 & 46 \\
\hline Ajudar os pais & 1 & 0,9 & 6 & 3,2 & 5 & 5,1 & 1 & 2,0 & 13 & 2,9 \\
\hline Total & 109 & 100,0 & 185 & 100,0 & 98 & 100,0 & 51 & 100,0 & 443 & 100,0 \\
\hline \multicolumn{11}{|l|}{ Nível de escolaridade dos não frequentes } \\
\hline Sem alfabetização & 8 & 7,3 & 10 & 5,4 & 7 & 7,1 & 2 & 3,9 & 27 & 6,1 \\
\hline Fundamental incompleto & 38 & 34,9 & 84 & 45,4 & 53 & 54,1 & 23 & 45,1 & 198 & 44,7 \\
\hline Fundamental completo & 11 & 10,1 & 17 & 9,2 & 6 & 6,1 & 3 & 5,9 & 37 & 8,4 \\
\hline Médio incompleto & 15 & 13,8 & 31 & 16,8 & 9 & 9,2 & 8 & 15,7 & 63 & 14,2 \\
\hline Médio completo & 31 & 28,4 & 35 & 18,9 & 20 & 20,4 & 13 & 25,5 & 99 & 22,3 \\
\hline Superior incompleto & 1 & 0,9 & 3 & 1,6 & 0 & 0,0 & 2 & 3,9 & 6 & 1,4 \\
\hline Superior completo & 5 & 4,6 & 5 & 2,7 & 3 & 3,1 & 0 & 0,0 & 13 & 2,9 \\
\hline Total & 109 & 100,0 & 185 & 100,0 & 98 & 100,0 & 51 & 100,0 & 443 & 100 \\
\hline
\end{tabular}

Tabela 7 - Frequência a escola, motivo da não frequência e nível de escolaridade do responsável pela família - Bairros Bela Vista, Castelo Branco, Pedregal, Renascer - Cuiabá/MT

Fonte: Autodeclaração - Instrumentos de Pesquisa

Ao se analisar as escolas e modalidades de cursos frequentados pelos responsáveis pela família constatou-se que 16 estudam em escolas do ensino fundamental e médio e 7 frequentam escolas que possuem apenas o ensino fundamental sendo que, apenas um responsável cursa pós-graduação em nível de Mestrado. A localização geográfica das escolas é notória a frequência em instituições do bairro e das áreas circunvizinhas, com exceção dos entrevistados de cursos superiores e profissionalizantes.

A Tabela 8 mostra que $19(1,6 \%)$ pessoas dos demais membros que compõem a família são Portadores de Necessidades Especiais - PNE, sendo 4 (1,2\%); no bairro Bela Vista; 7 (1,5\%) no Castelo Branco; $4(1,5 \%)$ no Pedregal e 4 no Renascer $(3,1)$ e, destes foram declarados PNE: 10 pessoas $(52,6 \%)$ com problemas mentais; $6(31,6 \%)$ visuais; $1(5,3 \%)$ motora e os demais percentuais ficaram distribuídos no item "outras doenças" inserido no instrumento de pesquisa.

O maior percentual de PNE com problemas mentais encontram-se no bairro Castelo Branco (4); 3 no Pedregal; 1 no Renascer e 2 no Bela Vista. Os PNE com problemas visuais estão distribuídos da seguinte forma: 3 no bairro Renascer e 1 caso em cada um dos outros 3 bairros. Desse modo, o remanejamento necessitará de atenção especial para o número elevado de casos de doenças mentais no tocante ao atendimento médico especializado e para o auxílio de todos os tipos inseridos nas relações de parentesco e vizinhança. 


\begin{tabular}{|c|c|c|c|c|c|c|c|c|c|c|}
\hline \multirow{2}{*}{$\begin{array}{c}\text { Demais membros da família portadores de } \\
\text { necessidades especiais e tipo de necessidade } \\
\text { especial }\end{array}$} & \multicolumn{2}{|c|}{ Bela Vista } & \multicolumn{2}{|c|}{$\begin{array}{l}\text { Castelo } \\
\text { Branco }\end{array}$} & \multicolumn{2}{|c|}{ Pedregal } & \multicolumn{2}{|c|}{ Renascer } & \multicolumn{2}{|c|}{ Total } \\
\hline & $\mathrm{N}$ & $\%$ & $\mathrm{~N}$ & $\%$ & $\mathrm{~N}$ & $\%$ & $\mathrm{~N}$ & $\%$ & $\mathrm{~N}$ & $\%$ \\
\hline Necessidades especiais & 4 & 1,2 & 7 & 1,5 & 4 & 1,5 & 4 & 3,1 & 19 & 1,6 \\
\hline Dados ausentes & 324 & 98,8 & 470 & 98,5 & 258 & 98,5 & 125 & 96,9 & 1177 & 98,4 \\
\hline Total & 328 & 100,0 & 477 & 100,0 & 262 & 100,0 & 129 & 100,0 & 1196 & 100,0 \\
\hline \multicolumn{11}{|l|}{ Tipos de necessidades especiais } \\
\hline Visual & 1 & 25,0 & 1 & 14,3 & 1 & 25,0 & 3 & 75,0 & 6 & 31,6 \\
\hline Mental & 2 & 50,0 & 4 & 57,1 & 3 & 75,0 & 1 & 25,0 & 10 & 52,6 \\
\hline Motora & 1 & 25,0 & 0 & 0,0 & 0 & 0,0 & 0 & 0,0 & 1 & 5,3 \\
\hline Auditiva & 0 & 0,0 & 0 & 0,0 & 0 & 0,0 & 0 & 0,0 & 0 & 0,0 \\
\hline Outro & 0 & 0,0 & 2 & 28,6 & 0 & 0,0 & 0 & 0,0 & 2 & 10,5 \\
\hline Dados ausentes & 0 & 0,0 & 0 & 0,0 & 0 & 0,0 & 0 & 0,0 & 0 & 0,0 \\
\hline Total & 4 & 100,0 & 7 & 100,0 & 4 & 100,0 & 4 & 100,0 & 19 & 100,0 \\
\hline
\end{tabular}

Tabela 8 - Demais Membros da Família Portador de Necessidades Especiais e Tipo de Necessidades Especiais- Bairros Bela Vista, Castelo Branco, Pedregal e Renascer - Cuiabá/MT

Fonte: Autodeclaração dos entrevistados; Pesquisa de Campo/Nov. 2011

Dados ausentes - número de pessoas que não responderam a questão ou que não se enquadram na temática da tabela

\section{Trabalho e da renda}

Há relativo consenso de que o desenvolvimento de um grupo social independentemente do seu tamanho, passa pelas atividades econômicas que desenvolve e pela renda obtida, entretanto as fontes de renda familiar nem sempre estão inseridas no mercado formal de trabalho com direitos trabalhistas assegurados. A presente seção busca fornecer informações sobre as condições de trabalho e de renda das famílias, com base exclusivamente na autodeclaração dos entrevistados. De forma concomitante, busca classificar os bairros impactados por meio da metodologia adotada pelo Instituto de Pesquisas e Desenvolvimento Urbano - IPDU da Prefeitura Municipal de Cuiabá.

Os dados referentes aos responsáveis pela família que trabalham com carteira assinada e realizam "bicos", ou seja, trabalhos temporários estão apresentados na tabela 9.

\begin{tabular}{|c|c|c|c|c|c|c|c|c|c|c|}
\hline \multirow{2}{*}{$\begin{array}{l}\text { Responsável pela família que trabalha } \\
\text { com carteira assinada e faz "bico" }\end{array}$} & \multicolumn{2}{|c|}{ Bela Vista } & \multicolumn{2}{|c|}{$\begin{array}{l}\text { Castelo } \\
\text { Branco }\end{array}$} & \multicolumn{2}{|c|}{ Pedregal } & \multicolumn{2}{|c|}{ Renascer } & \multicolumn{2}{|c|}{ Total } \\
\hline & $\mathrm{N}^{*}$ & $\%$ & $\mathrm{~N}$ & $\%$ & $\mathrm{~N}$ & $\%$ & $\mathrm{~N}$ & $\%$ & $\mathrm{~N}$ & $\%$ \\
\hline \multicolumn{11}{|l|}{ Possui carteira assinada } \\
\hline Sim & 51 & 42,1 & 77 & 38,7 & 38 & 35,8 & 16 & 28,1 & 182 & 37,7 \\
\hline Não & 70 & 57,9 & 122 & 61,3 & 68 & 64,2 & 41 & 71,9 & 301 & 62,3 \\
\hline Dados ausentes & 4 & & 7 & & 5 & & 0 & & 16 & \\
\hline Total $^{\star \star}$ & 125 & 100,0 & 206 & 100,0 & 111 & 100,0 & 57 & 100,0 & 499 & 100,0 \\
\hline \multicolumn{11}{|l|}{ Faz "bico" } \\
\hline Sim & 39 & 33,1 & 75 & 39,5 & 34 & 33,0 & 27 & 48,2 & 175 & 37,5 \\
\hline Não & 79 & 66,9 & 115 & 60,5 & 69 & 67,0 & 29 & 51,8 & 292 & 62,5 \\
\hline Dados ausentes & 7 & & 16 & & 8 & & 1 & & 32 & \\
\hline Total & 125 & 100,0 & 206 & 100,0 & 111 & 100,0 & 57 & 100,0 & 499 & 100,0 \\
\hline
\end{tabular}

Tabela 9 - Total de Responsáveis pela Família que trabalham com carteira assinada e realizam trabalhos temporários 'bico'- Bairros Bela Vista, Castelo Branco, Pedregal e Renascer - Cuiabá/MT

Fonte: Autodeclaração dos entrevistados -

Os maiores percentuais estão entre os entrevistados que não trabalham com carteira assinada $(37 \%)$ e aqueles que desenvolvem atividades informais $(37,5 \%)$. Entre os demais membros da família mais de $70 \%$ não possuem carteira assinada e mais de $80 \%$ não fazem "bico" para 
auxiliar na renda da família (Tabela 9). A situação vivenciada pelo percentual de famílias impactadas é preocupante, pois cruza com as informações sobre o trabalho na família onde foi ressaltado que grande parte dos demais membros da família não exerce atividade remunerada. Desta forma, um percentual considerável de responsáveis pelas famílias arcam sozinhos com as despesas do domicílio.

$\mathrm{Na}$ área investigada detectou-se que alguns entrevistados responsáveis pela família diversificam as fontes de renda por meio do aluguel de imóveis (partes do domicilio ou outros imóveis de sua propriedade - Figura 6).

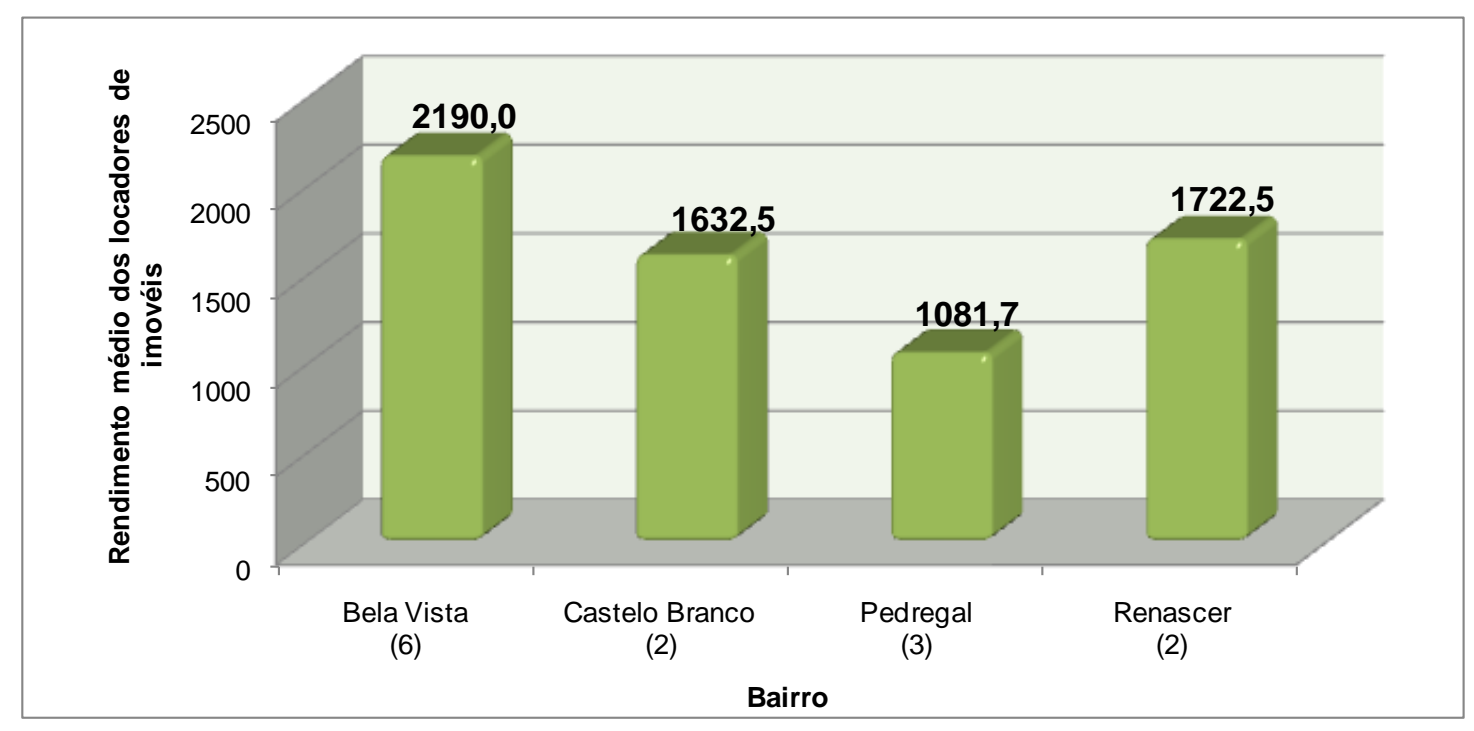

Figura 6- Rendimento Médio $(R \$)$ dos locadores de Imóveis - Bairros Bela Vista, Castelo Branco, Pedregal e Renascer - Cuiabá/MT

Fonte: Autodeclaração dos entrevistados

Nos depoimentos registrados é frequente a afirmação que o entrevistado "sente-se feliz morando no Bairro". Entre os fatores citados para justificar tal afirmativa está o nascimento dos filhos, o crescimento e a multiplicação das famílias, que se percebem nucleares e extensas, e ainda várias elementos do universo simbólico que permeiam os valores humanos e os sentimentos forjados nas instituições como as famílias, igrejas, escolas e creches, associações e outros setores como no comércio, nas ruas, quintais e moradias. As relações de sociabilidade se desenvolvem nestes e em outros espaços apresentados, dos quais se ressalta o fato de que $46 \%$ dos entrevistados (responsáveis pelas famílias) frequentam igrejas; no caso dos sindicatos a frequência é de $14,5 \%$, sendo que a baixa estatística é atribuída a existências de poucas destas instituições nos bairros e, por outros a não existência, como o caso de Cooperativa, Grupo ou Associação Cultural, ONG ou Grupo cívico.

No tocante à pergunta aberta: "Quais são as suas preocupações com a construção da Avenida Parque do Barbado?" a grande maioria dos entrevistados mostrou apreensão com a nova realidade e as ações do poder público, que estão expressas em algumas respostas como:

"A minha preocupação é que levem a gente para lugar longe do centro, por que meu menino anda na cadeira de rodas e estuda. Então fica difícil. E também por causa da igreja que congrego aqui no bairro próximo. Só isso mesmo." (M.S.P.B -Bairro Bela Vista).

"A avenida tem que existir, mas não se faz progresso sem olhar a comunidade que está entorno dele. Além de uma faixa de piche e uns meios fios pintados. Nesse local foram criadas pessoas, crianças que hoje se tornam adultos sem uma perspectiva de uma vida melhor devido ao progresso". (L. C. C. V. - Bairro Castelo Branco) 
"Tenho preocupação de sair da casa e não saber para onde ir. Foi à única coisa que construímos na vida e vão tirar da gente". (L. T. M-Bairro Pedregal)

" A preocupação de mudar, todo mundo tem. Não é só eu não! aqui que a gente trabalha, a casa é grande, a gente não sabe se lá vai ser. Se ganharemos casa ou indenização. E para onde vamos? Ninguém sabe! ( P.S.B-Bairro Renascer).

" A minha preocupação é deles vim e jogar nós pra longe e deixar sem lugar, mandar prá um bairro distante que a gente não conhece, não tem escola nem posto de saúde." (E.S.P- Bairro Pedregal).

" Eles falam que vão tirar a gente daqui e nunca resolvem! Me preocupo se tirar a gente daqui e mandar para um lugar longe do serviço... onde pode ser um lugar com muita droga!"( $\mathrm{F}$. A. L. S - Bairro Renascer).

Dessa forma, com base nos resultados das informações coletadas in loco o prognóstico foi organizado em etapas individuais onde o diagnóstico das temáticas investigadas gerou os principais aspectos das propostas e, a partir deste quadro, foi delineado os correspondentes cenários desejados pela população impactada à partir das dimensões, a saber: social, econômica, educacional e política. Tais informações possibilitaram a geração de um quadro sucinto do diagnóstico onde os problemas e benefícios foram apontados.

Assim sendo, na Dimensão Social, no que se referem às Relações Sociais de Parentesco e de Vizinhança os entrevistados se preocupam com o remanejamento porque moram próximos aos demais membros da família e cultivam relações de sociabilidade e de afeto com estes e a vizinhança;

- $64,6 \%$ dos responsáveis pelo domicilio tem um ou mais parentes que moram no mesmo bairro. Estes declararam visitar seus parentes em média 15 vezes por mês;

- Do total de responsáveis pela família 54,8\% declararam residir em Cuiabá há mais de 25 anos e no bairro de 20 a 25 anos (23,4\%). Essa parcela da população, acrescida das demais, estabeleceram fortes relações de sociabilidade por convívio e consanguinidade.

$\mathrm{Na}$ questão da Habitação Os domicílios onde vivem as famílias foram construídos com grandes sacrifícios financeiros ao longo dos anos de permanência no bairro. Alguns estão inacabados e outros ainda encontram-se em construção;

- 275 famílias residem em domićlios unifamiliares e 123 em domicílios multifamiliares, com duas ou mais famílias. Aproximadamente $80 \%$ são casas individualizadas em um terreno, sendo que $8,3 \%$ habitam em casas de cômodos;

- Apenas $13,9 \%$ dos domicílios estão escriturados com destaque para $41,6 \%$ no Bairro Bela Vista;

- 76,8\% das famílias declararam residir em domicilio próprio, 13,8\% em alugados e 9,4\% em cedidos.

$\mathrm{Na}$ questão da Infraestrutura Urbana entre os problemas mais graves, na percepção dos entrevistados, está a ausência de rede de esgoto, a ineficiência de transporte coletivo eaausência de pavimentação asfáltica ocupando o terceiro e o quarto lugar, respectivamente;

- 24\% dos domicílios estão localizados em ruas asfaltadas e $75 \%$ em rua de terra;

- Apenas $12 \%$ dos domicílios possuem laje de concreto e $25,5 \%$ tem forro de madeira $(56,5 \%)$ seguido do pvc $(34,3 \%)$;

- Os quintais dos domićlios são utilizados para lazer $(45,1 \%)$, pomar $(18,2 \%)$,plantio para subsistência $(6,1 \%)$ e criação de pequenos animais $(9,1 \%)$; 
- A rede de água municipal (SANECAP) foi apontada como a principal fonte de abastecimento de água do domićlio ( $86 \%)$; a regularidade média de abastecimento de água é de 6 dias por semana, portanto, não falta água;

- O serviço público de coleta de lixo atende 45,5\% da população de 2 a 3 dias por semana;

- 79,9\% dos domićlios apontam o Córrego do Barbado como o local de destino do esgoto;

No tocante à Infraestrutura adequada aos PNE - Portadores de Necessidades Especiais, nos bairros onde vivem não há atenção especial aos doentes mentais, deficientes visuais, cadeirantes e outros portadores de necessidades especiais.

- Entre os responsáveis pela família 6,4\%(32 pessoas) são portadores de necessidades especiais, destes destaca-se cerca de $15 \%$ visual, $15 \%$ mental, 9,4\% motora e $6,3 \%$ auditiva.

Na Saúde foi apontada a insuficiência de postos de saúde próximos e de qualidade para o atendimento da população residente nos bairros impactados.

Entre os problemas mais graves, que podem estar ocorrendo no bairro, a ausência de opções de lazer ocupa o sétimo lugar na percepção dos entrevistados.

Nos bairros onde vivem existem poucos e precários locais para a prática esportiva.

Entre os problemas mais graves, que ocorrem no bairro, na percepção dos entrevistados, as drogas ocupam o primeiro lugar seguido da insuficiência de policiamento. Os assaltos ocupam o quinto lugar por nível de gravidade.

Na dimensão Econômica, no que se refere às questões relacionadas ao Genero, Trabalho, Emprego e Renda constatou-se que263 mulheres (52,7\%) são responsáveis pela família e 123 $(24,6 \%)$ responsáveis pela família do sexo feminino são solteiras, ou desquitadas ou divorciadas ou viúvas e são mães;

- A preocupação central está no remanejamento, especificamente com a localização da nova moradia em relação a distancia das escolas frequentadas pelos filhos e à proximidade dos locais de trabalho (Bairro Terranova, Jardimitália, Residencial Alphaville, Shopping Pantanal, Três Américas e entorno);

- A mudança para o novo local, se longínquo, pode resultarem despesas adicionais com transporte público ou privado;

- Dependência dos laços de parentesco e de vizinhança em várias instâncias, inclusive no cuidado com os filhos;

- Os maiores percentuais $(74,2 \%)$ da população da área impactada está na faixa etária entre 20 a 50 anos e $25,8 \%$ não contribuem com o sustento familiar, provavelmente dada a falta de oportunidade de emprego;

- Estima-se que aproximadamente $74 \%$ dos entrevistados (masculino e feminino) mantêm individualmente as famílias;

- Cerca de 50\% dos responsáveis pela família não trabalham com carteira assinada;

- Aproximadamente $37 \%$ dos responsáveis pela família que tem carteira assinada necessitam realizar trabalhos temporários (bicos) para complementar a renda familiar;

- A renda média familiar do mês de referencia (outubro/2011) resulta em um índice classificado como baixo (Bairros Castelo Branco, Pedregal e Renascer) e médio-baixo (Bela Vista);

- O número médio de membros das famílias não chega a 4 pessoas, entretanto, por se tratar de média, tal índice não expressa a realidade das famílias mononucleares extensas;

- No mês de referencia (outubro/2011) constatou-se que51 pessoas recebiam segurodesemprego. Tal dado revela por um lado, o desemprego, por outro, uma fonte de renda adicional para o sustento familiar;

- A Bolsa-família recebida por 95 pessoas significa que é o programa social que tem maior contribuição no incremento da renda familiar; 
- Detectou-se que alguns imóveis localizados na área impactada são alugados. Alguns proprietários vivem no mesmo bairro destes imóveis, cujo aluguel gera acréscimos nos totais de renda;

- Constata-se um desequilíbrio entre a receita e a despesa das famílias que necessitam gastar mais do que ganham;

$\mathrm{Na}$ dimensão Educação, no que tange à Educação formaldetectou-se que 163 membros das famílias encontram-se na faixa etária até cinco anos, sendo que destas aproximadamente $55 \%$ não frequentam a escola;

- No universo de 499 responsáveis pela família, 443 declararam não frequentar a escola, ou seja, $89,3 \%$. Quando questionados os motivos da não frequência, $45,8 \%$ mencionaram a necessidade de trabalhar para garantir o sustento familiar como o principal argumento.

- Dos responsáveis pela família que não frequentam as unidades escolares, 44,7\% possuem o Nível Fundamental Incompleto e 22,3\% concluíram o Ensino Médio.

- 22,6\% estudam próximo à residência e 7,5\% que estudam no próprio bairro do domicilio;

- A faixa etária que contempla dos "20 até 40 anos" tem 356 pessoas, das quais 124 (34,8\%) com o nível de escolaridade Ensino Fundamental Incompleto. Ressalta-se que na faixa dos 40 à 60 anos 4 pessoas possuem Curso Superior completo e 1 encontra-se com pós-graduação incompleta

Quanto aos Bens Culturais, aproximadamente $46,7 \%$ dos responsáveis pelas famílias afirmam que existem bens culturais na história do bairro e as instituições religiosas foram apontadas como os bens culturais mais importantes $(63,5 \%)$.

Desta forma evidenciou-se que as questões ambientais como a ocupação de áreas de riscos em APP's, os episódios de enchentes, inundações e a poluição do Córrego do Barbado em praticamente toda a sua extensão praticamente não foram considerados pela população entrevistada que coloca os problemas sociais e econômicos como foco de angústia caso o processo de remanejamento seja efetivado pelo poder público.

\section{CONCLUSÕES}

Diante do exposto, o presente estudo objetivou apresentar o perfil socioeconômico da população residente no percurso onde será construída a Avenida Parque do Barbado Cuiabá/MT e verificar porque ela continua vivendo em áreas de riscos (APP's).

É importante ressaltar que este estudo não contempla a etapa de execução nem tampouco, apresenta autonomia para deliberações haja vista ser este o papel do poder público, cabendo à população envolvida definir as formas de organização para participarem da gestão das ações.

Conclui-se, lembrando que a Topofilia, ou o sentimento de amor pelo lugar, se soma as relações de sociabilidades estabelecidas entre os familiares, amigos e vizinhos que os identifica entre si; e estas, se fortalecem pela convivência com objetivos diversos em diferentes ambientes públicos e privados gerando na dimensão da cultura imaterial os Bens Culturais que integram o Patrimônio Histórico Cultural dos bairros Bela Vista, Castelo Branco, Pedregal e Renascer e a própria cidade de Cuiabá.

Assim, a forma de ocupação espacial encontrada na área da pesquisa, bem como as condições socieconômicas da população local expressou, em escala de bairros, um exemplo do que ocorre nas áreas urbanas brasileiras no que tange a produção de espaços desiguais e conflitantes, onde diferentes classes sociais convivem lado a lado em termos de localização geográfica e exposição aos perigos derivados de uma área de riscos.

Grande parte da população entrevistada demonstrou angústia com a questão da agilização nas informações sobre as condições que envolvem o remanejamento, pois não conseguem estabelecer rotinas de reformas e benfeitorias em seus imóveis. Além disso, necessitam rever planejamentos no que se refere à localização da nova moradia em relação a distancia das escolas frequentadas pelos filhos e à proximidade dos locais de trabalho da família. Na esteira de preocupações com o remanejamento, também, se encontra a situação delicada dos moradores portadores de necessidades especiais (PNE) que vivem nos bairros. 
Desse modo, espera-se por parte dos órgãos de gestão e decisão pública, que o processo de remanejamento da população investigada, seja realizado com base na realidade socioeconômica da população local de forma que garanta a dignidade de todas as pessoas envolvidas, que elas recebem locais de residência, moradias e relações familiares e de amizades próximas às que possuem agora.

Que o presente estudo possa contribuir com informações sobre o sentimento de pertencimento desta população em relação ao lugar, mesmo sendo área de risco à inundações, alagamentos e outros problemas socioambientais que podem gerar problemas de saúde, perdas materiais e dependendo da magnitude do evento até perdas de vidas.

\section{Bibliografia}

ARAÚJO, Suely Mara Vaz Guimarães. As Áreas de Preservação Permanente e a Questão Urbana. Estudo Técnico. Consultoria Legislativa da Câmara dos Deputados. Brasília - DF: agosto de 2002.

BORDEST, Suise Monteiro Leon. A Bacia do Córrego Barbado. Cuiabá: Gráfica Print, 2003.

BRASIL. Ministério do Meio Ambiente. Conselho Nacional do Meio Ambiente Resolução Conama $\mathbf{n}^{\circ}$ 001. 1986. Disponível em:www.mma.conama.gov.br/conama> Acesso em $17 / 04 / 2006$.

Resolução Conama no 369, de 28/03/2006. Dispõe sobre os casos excepcionais, de utilidade pública, interesse social ou baixo impacto ambiental, que possibilitam a intervenção ou supressão de vegetação em Área de Preservação Permanente - APP.

Constituição (1988). Constituição da República Federativa do Brasil: promulgada em 5 de outubro de 1988. Contêm as emendas constitucionais posteriores. Brasília, DF: Senado, 1988.

. Lei No. 9.985/2000, de 18 de julho de 2000. Sistema Nacional de Unidades de Conservação. Brasília, DF: Senado, 2000.

Lei Federal No 4.771, de 15 de setembro de 1965. Estabelece o Código Florestal Brasileiro. Diário Oficial da República Federativa do Brasil. Brasília, DF. 16 Set. 1965.

Lei Federal No. 6.766/79, após alterações impostas pela LEI FEDERAL 9785/99, Artigo 40. Item III. Brasília, DF: Senado, 1979.

.LEI Federal $\mathbf{N}^{\circ}$. $\mathbf{6 . 9 3 8 / 8 1}$ alterada pela Lei Federal 7.804/89 que institui a Política Nacional do Meio Ambiente. Brasília, DF: Senado, 1981.

Lei Federal No 9.605,de 12 de fevereiro de 1998. Sanções penais e administrativas derivadas de condutas e atividades lesivas ao meio ambiente. Brasília, DF: Senado, 1998.

Decreto No. 3.179 de 21 de setembro de 1999. Brasília, DF: Senado, 1999

Senado, 2001.

Lei No. 10257/01, de 10 de Julho de 2001.Estatuto das Cidades Brasília, DF:

Plano Diretor Participativo de Cuiabá. SEPLAN - Secretaria Municipal de Planejamento. Cuiabá-MT: Prefeitura de Cuiabá, 2010.

GUARIM, G.N. Diagnóstico Florístico e Faunístico da cidade de Cuiabá. Relatório de Pesquisa - Cuiabá, MT: Universidade Federal de Mato Grosso; Prefeitura Municipal de Cuiabá. 1990.

iBge. - instituto bRASileiro DE GEOgRAfiA E eStATÍsticA. Censo Demográfico 2010. Rio de Janeiro: IBGE, 2011.

KOTHARI, Miloon. Direito à moradia. http://direitoamoradia.org/?cat=216\&lang=pt acessado em 15 de dezembro de 2011 
MAITELLI, G. T. \& ZAMPARONI, C. A. G. P. Climatologia urbana: uma revisão bibliográfica. Cuiabá: Revista Mato-Grossense de Geografia, n. 0, p. 159-196, 1995.

MORAES, Wagner de oliveira. O Processo De Ocupação Ilegal no Espaço Urbano de Cuiabá: Os Casos dos Bairros Pedregal e Renascer. Dissertação de Mestrado do Programa dePós-graduação em Geografia da Universidade Federal de Mato Grosso - UFMT. Cuiabá-MT, Julho. 2009

MOURA, R.; ULTRAMARI, C. O Que é Periferia Urbana. São Paulo: Brasiliense, vol. 306, 1996. (Coleção Primeiros Passos)

OLIVEIRA, Marcelo Accioly Teixeira; HERRMANN, Maria Lúcia de Paula. Ocupacão do Solo e Riscos Ambientais na Área Conurbada de Florianópolis. In: GUERRA, Antônio José Teixeira; CUNHA, Sandra Baptista. (orgs.) Impactos Ambientais Urbanos no Brasil. Rio de Janeiro: Bertrand Brasil, 2001.

PINTO, A. L.; CARVALHO, E.M. de; SILVA, P. V. de. Riscos naturais e carta de riscos ambientais: um estudo de caso da bacia do córrego fundo, Aquidauana/MS. Climatologia e estudos da paisagem. Rio Claro, v.2, n.1, janeiro/junho/2007. Disponível em: $<$ http://cecemca.rc.unesp.br/ojs/index.php/climatologia/article/.../653> Acesso em 05 mai. 2012

RODRIGUES, Arlete Moysés. Produção e consumo do e no espaço: problemática ambiental urbana. São Paulo: Hucitec, 1998.

SERVILHA, Elson Roney (et al). Conflitos na Proteção Legal das Áreas de Preservação Permanentes Urbanas. I Seminário do Laboratório Fluxus - Faculdade de Engenharia Civil, Arquitetura e Urbanismo - FEC, UNICAMP. SP. 2006.

SOJA, Edward N. Geografias pós-modernas: a reafirmação do espaço na teoria social crítica. Rio de Janeiro: Zahar, 1993.

SUERTEGARAY, Dirce Maria Antunes. Espaço geográfico uno e múltiplo. In: SUERTEGARAY, Dirce Maria Antunes; BASSO, Luís Alberto; VERDUM, Roberto. (orgs). Ambiente e Lugar no Urbano: a Grande Porto Alegre. Porto Alegre : Ed. Universidade/UFRGS, 2000. 239p. 